Journal of Social Sciences (COES\&RJ-JSS)

ISSN (E): 2305-9249 ISSN (P): 2305-9494

Publisher: Centre of Excellence for Scientific \& Research Journalism, COES\&RJ LLC

Online Publication Date: $1^{\text {st }}$ October 2016

Online Issue: Volume 5, Number 4, October 2016

http://centreofexcellence.net/J/JSS/JSS\%20Mainpage.htm

\title{
The contribution of capital investment and selling expenses on sales revenue: An analytical study of Jordanian industrial corporations (2004-2014)
}

\begin{abstract}
Adnan Gharaibeh
The University of Jordan

Abstract:

This paper investigates how sales revenue are influenced by increasing the amount of investment in fixed assets and distribution expense's derived from corporate financial reports, the study used sales revenue, fixed assets, selling \& distribution expenses, and lag of fixed assets as nonprofit parameters. We examined the financial statements of (11) industrial sector listed on Amman Stock Exchange for the period 2004 to 2014. The result shows that The results shows a positive relationship between sales revenue with fixed assets and selling \& distribution expenses, and insignificant relationship between the lag variable of fixed for one year, and sales revenue,. The study concluded that lag of fixed assets indicators were less valued in capital investment decisions during this period.
\end{abstract}

Keywords:

Fixed assets, sales revenue, industrial sector

\section{Citation:}

Gharaibeh, Adnan (2016); The contribution of capital investment and selling expenses on sales revenue: An analytical study of Jordanian industrial corporations (2004-2014); Journal of Social Sciences (COES\&RJ-JSS), Vol.5, No.4, pp: 540-547. 


\section{Introduction:}

Managers often consider decisions that involve an investment today in the hope of realizing future profits, such as the purchase of new equipment or the introduction of new products (non-current investment decision). These investments face many constraints the most is the funding for these investment and the costs related of these decisions. These decisions vary from one company to another depending on the nature and size of the company. However, the investment in fixed assets represents the core of the firm activities of firms to produce goods, but this type of investment results in a set of commitments difficult to reverse it, and expects to get a return on them after a relatively long period. Fixed assets represent a high percentage of total assets in all manufacturing firms, so it increases the risk of the uncertainty of future cash flows.

Most studies investigate the effect of revaluation of fixed assets and future performance and annual return, industrial leverage and share performance before the revaluation of assets, distributor satisfaction in mediating the association between market orientation in distribution and return on assets, financial ratios and it's influenced by the economic crisis as profit margin and rates of turnover, and return on equity. But This study investigate the use the change in the value of fixed assets lag of fixed assets and distribution expenses not the financial ratio and their effect on sales revenue for Jordanian manufacturing firm.

\section{Literature Review}

Chiquan Wang (2016) explored the role of distributor satisfaction in mediating the association between market orientation in distribution and return on assets. Results showed that the positive relationship between market orientation in distribution and distributor satisfaction was strongly supported. While distributor orientation and competitor orientation were both positively related to distributor satisfaction and return on assets, interfunctional coordination was not related to either distributor satisfaction or return on assets.

Irina and Elvira (2014) examined the relationship between return on equity and other company characteristics. These characteristics can be classified in two broad groups: ratios (return on assets, return on sales and current ratio), and capital structure ratios (total debt, long-term debt and short-term debt ratios). In addition, the ratio of tangible assets and company size were analyzed. It can be concluded that agriculture companies did not have volatile ROE in the period of the study, and during recession, this ratio remained above $10 \%$. Such situation can be explained by government policies and subsidies. Therefore, ROE of agriculture companies is not generally associated and correlated with other company characteristics. In the case of food production companies, one can find that during the recession more companies that are profitable have less debt (regardless of maturity). For retail companies, it can be concluded that bigger companies have a higher $\mathrm{ROE}$, yet asset structure and long-term debt ratio are negatively correlated with ROE.

In Naser et al. (2013) study six variable included size, profitability, financial leverage, fixed asset, industry type and ownership structure have chosen and the purpose is determining whether these six variable have any effect on the tax rate or not? Results are shown that four out of six variables (size, financial leverage, and ownership structure and industry type) have affected the tax rate. Automotive, pharmaceutical, chemical, 
The contribution of capital investment....

machinery, cement, food, metal and tile industries par more tax than others do and also companies that have more than $50 \%$ ownership of the stock are paying tax more than other companies. These results are achieved in a situation if the tax authorities and auditors acted according to the law and regulations, there will be no factor to affect the payable tax system and show growth or reduction. In this direction, psychological factors and the auditors' different interpretation about taxable income taxes should be taken to consideration. For instance, a company that has more fixed assets is an agent, which will affect the auditors and causes to receiving more taxes from the company.

Muaaz Alasqah (2012) attempted to investigate the firm's opportunity cost resulting from not fully utilizing its investment capacity (assets) and how this opportunity cost is associated with the firm's value within the context of the life-cycle theory. This study concluded that investor places a higher value on firms that generate profits from core business operations higher than profits from non-core business operations. Moreover, investors perceive our construct of opportunity cost positively whenever it deviates further from zero.

Marian et al. (2012) concluded that the profitability of the Romanian firms declined as a result of the economic crisis. Before crisis, it was significantly influenced by the financial structure and the financial balance. After the crisis, the importance of business administration indicators (as profit margin and rates of turnover) increased, but also of the random external factors, uncontrollable by the management. We can say that certain financial ratios were influenced by the economic crisis, while others have not had such an influence. Ratios of return are among the most exposed to economic crisis. Other financial ratios studied in this article were not significantly influenced by the economic crisis as they either grew (such as liquidity and solvency ratios) or stagnated.

S. Francisco et al, (2012) The purpose of this paper is to investigate the impact of ISO 9000 certification on three dimensions of firm performance that are theoretically derived to have a relationship with the adoption of ISO 9000 standards, namely, sales revenue, cost of goods sold/sales revenue, and the asset turnover ratio (sales/total assets).Employing a panel data approach covering all publicly traded companies in Brazil that had adopted the ISO 9000 standards from 1995 to 2006, the study investigate the impact of the certification on firm performance using three categories of economic regression models: the pooling of cutting data with ordinary least squares, the fixed effects and the random effects. Findings that ISO 9000 certification is found to be associated with an increase in sales revenues, decrease in cost of goods sold/sales revenue and increase in the asset turnover ratios of the certified firms.

Amit and Dominique (2010) investigated one important aspect of the long-term relationship between advertising spending and market capitalization. The authors hypothesize that advertising can have a direct effect on valuation (i.e., an effect beyond its indirect effect through sales revenue and profit response). The empirical results across two industries provide support for the hypothesis that advertising spending has a positive, long-term impact on own firms' market capitalization and may have a negative impact on the valuation of a competitor of comparable size.

Agnes, et al. (2009) stated that UK firms with higher industrial leverage and share performance two years before the revaluation year are inclined to write up their assets, 
suggesting that firms choose not to recognize good news unless it has been supported by their superior market performance and industry norm. This finding differs from the leverage reduction as well as the signaling objective suggested by previous literature.

Jorge (2005) examined changes in performance for ERP-adopting firms versus nonadopting firms along the dimensions of asset utilization and return on sales. Asset utilization is more closely aligned with changes in leanness of operations, and return on sales is more closely aligned with customer-value-added. Finding that ERP-adopting companies performed relatively better in terms of asset turnover than non-ERP-adopting companies during both the implementation and post implementation periods and those ERP-adopting firms outperformed non-ERP-adopting firms in terms of return on sales during the post-implementation period. These findings indicate that the impact of ERP implementation on return on sales occurred after an assimilation period.

David, et al. (1999) revealed that revaluation of fixed assets in UK firms has significantly positive related to change in future performance and annual return, but weak relationship between future performance and prices for higher debt-to-equity ratio. Indicating motivation affects how Revaluations reflect asset value changes. The relations also are weaker for cross-listed Firms and in a more volatile economic period.

David P. Echevarria, (1997) US Companies were widely reported to be investing millions of dollars over the last two decades to upgrade manufacturing and operating facilities to increase competitiveness in the global marketplace. These investments should have resulted in increased profitability. The observed performance of Fortune 500 Industrial companies fell short of these goals. Moreover, this match with this study that insignificant relationships between the increase in fixed in the lag period for future earning, unless the relation is positive.

\section{Methodology \\ Data source}

The study depends on secondary data derived from Amman Stock Exchange for the period of 2004-2014 (www. ase.com).

\section{Data analysis}

Data were analyzed using and descriptive statistics, unit root test (DF test), multiple regression models, and ANOVA test.

\section{Descriptive statistics}

Some measures that are commonly used to describe a data set are measures of central tendency and measures of variability or dispersion. Measures of central tendency include the mean, median and mode, while measures of variability include the standard deviation (or variance), the minimum and maximum values of the variables.

Dickey-Fuller test

The Dickey-Fuller test, tests the null hypothesis of whether a unit root is present in an autoregressive model. The alternative hypothesis is different depending on which version of the test is used, but is usually stationarity or trend-stationarity. 
Multiple regression models

Regression analysis is a statistical process for estimating the relationships among variables. It includes many techniques for modeling and analyzing several variables, when the focus is on the relationship between a dependent variable and one or more independent variables (or 'predictors').

ANOVA provides a statistical test of whether or not the means of several groups are equal, and therefore generalizes the t-test to more than two groups. ANOVAs are useful for comparing (testing) three or more means (groups or variables) for statistical significance.

Model Population \& sample of study

This study aimed of identifying the impact of current assets change of the future earning of the manufacturing firms in Jordan.

\begin{tabular}{|c|l|c|}
\hline & Sector & Number \\
\hline 1. & Chemical Industries & 11 \\
\hline 2. & Electrical Industries & 6 \\
\hline 3. & Engineering and Construction & 10 \\
\hline 4. & Food and Beverages & 12 \\
\hline 5. & Glass and Ceramic Industries & 2 \\
\hline 6. & Mining and Extraction Industries & 14 \\
\hline 7. & Paper and Cardboard Industries & 3 \\
\hline 8. & Pharmaceutical and Medical Industries & 8 \\
\hline 9. & Printing and Packaging & 2 \\
\hline 10 & Textiles, Leathers and Clothing's & 6 \\
\hline 11. & Tobacco and Cigarettes & 2 \\
\hline & Totals & 75 \\
\hline
\end{tabular}

This study consists of main dependent variable, which is sales revenue, and three independent variable, fixed assets, selling \& distribution expenses and lag for fixed assets. Using panel data, to investigate the factors affecting the sales revenue (sales) in manufacturing corporations in Jordan. Using the analogical analysis method for multiple regression model using Ordinary Least Square's (OLS) according to following equation:

$Y=a+\log b_{1} X_{1}+\log b_{2} X_{2}+\log b_{3} X_{3}$

$\mathrm{Y}$ : sales volume (Depended Variable)

a: constant

$b_{1}, b_{2}$, and $b_{2}$ the slope of parameters of independent variables.

$\mathrm{X}_{1}$ : fixed assets.

$\mathrm{X}_{2}$ : Selling and Distribution Expenses.

$\mathrm{X}_{3}$ : lag for fixed assets. 


\section{Result and Analysis} 1.Descriptive statistics

\begin{tabular}{|l|c|c|c|c|}
\hline Variables & Max & Min & Mean & S.D \\
\hline Sales & 9.32 & 0 & 7.651 & $11.8 \%$ \\
\hline Fixed assets & 9.02 & 6.21 & 7.609 & $5.6 \%$ \\
\hline Sales expenses & 7.93 & 3.31 & 6.41 & 8.35 \\
\hline
\end{tabular}

Standard deviation of sales was high by $11.8 \%$ will the least Standard deviation for fixed assets $5.6 \%$ and this result seen to be normal since the sales prices are highly volatility than the price of fixed assets.

\section{Unit Root Test}

We used DF-test to examine data stationarity, and the result as below:

\begin{tabular}{|l|c|c|c|}
\hline Variables & F & Min & Sig \\
\hline Sales & -3.79 & $-2.88^{*}$ & 0.0041 \\
\hline Fixed assets & -2.96 & $2.88^{*}$ & 0.417 \\
\hline Sales expenses & -3.28 & $2.88^{* *}$ & 0.0036 \\
\hline
\end{tabular}

The three time series are stationary as compare the t- statistics with its critical value (taw table) so we reject the null hypotheses that state data are not stationary. Consequently, these results permit us to use the (OLS) since we avoid the problem of spurious.

3.Regression analysis (OLS)

\begin{tabular}{|l|c|c|c|}
\hline Variables & Coefficient & $\mathrm{T}$ & $\mathrm{p}$-value \\
\hline Intercept & -1.85 & -2.006 & $0.047^{*}$ \\
\hline $\mathrm{X} 1$ & 0.522 & 2.819 & $0.0057^{*} *$ \\
\hline $\mathrm{X} 2$ & 0.865 & 6.95 & $0.0000^{* *}$ \\
\hline $\mathrm{X} 3$ & 0.0133 & 0.042 & 0.966 \\
\hline *sig at 5\% **sig at 1\% & \\
\hline
\end{tabular}

1.There is a positive and significant relationship between the fixed, selling expenses, and sales revenue, mean that increase in fixed assets by $1 \mathrm{JD}$ will reflect by $0.522 \mathrm{JDin}$ sales. 2.The productivity of selling expenses is high in comparison with fixed assets since 1JD increase in selling expenses will produce 0.865 increases in sales revenue.

3.Will the lag of fixed assets seem to be insignificant which this result contractually to the theory that current increase in fixed will lead in future earning, unless the relation is positive.

4.ANOVAs test

\begin{tabular}{|l|c|c|c|}
\hline $\mathrm{F}$ & Sig f & $\mathrm{R}^{2}$ & Adj $^{2}$ \\
\hline 70.16 & $0.000 * *$ & 0.667 & $65.7 \%$ \\
\hline *sig at 5\% **sig at 1\% & \\
\hline
\end{tabular}


The model seems to be correctly specified the independent variable since the f-test was 70.16 and significant and the $\mathrm{R}^{2}$ high was closed to adjusted $\mathrm{R}^{2}$.

\section{Conclusion}

The aim of study is to examine the relationships between relationships between fixed assets(plant assets), selling \& distribution expenses, and lag variable of fixed for one year with sales (sales revenue) in industrial sector which consist around (75) firms distributed to (11) sector during the period 2004-2014. The results shows a positive and significant relationship between the fixed, selling expenses, and sales revenue, insignificant relationship between the lag variable of fixed for one year, and sales revenue, which mean:

1.May by the management concentrate most of its investment to nonproductive assets or inefficiency in managing its rescores?

2.As well as the surrounding Middle East, political crises in Syria, Iraq, and Yemen, which decrease the export in the later of year's new equipment, purchased and installed?

3.Make more studies to attain more information about the investing in fixed assets and which factor has more influence on sales revenue.

\section{References:}

1.Agnes, C., Stephen W.J. LIN (2009),"When do firms revalue their assets upwards? Evidence from the UK", International Journal of Accounting \& Information Management, Vol. 17 Iss 2 pp. 166 - 188.

2.Alshomaly. I 2014. Bank diversification \& the systematic risk of equity portfolio, European Scientific Journal.10 (16), 171-184.

3.Alshomaly. I 2013. Performance Evaluation and Responsibility Accounting, Journal of Management Research 5 (1), 291-301.

4.Amit. J, Dominique. M 2010, The Direct and Indirect Effects of Advertising Spending on Firm Value, Journal of Marketing, Vol. 74, 20-33.

5.Chiquan .G.Y. Wang, 2016,"Market orientation, distributor relationship, and return on assets ", Asia Pacific Journal of Marketing and Logistics, Vol. 28 Iss 1 pp. $107-123$.

6.David, A., Mary, B., Ron, K., 1999. Revaluations of fixed assets and future firm performance: Evidence from the UK. Journal of Accounting and Economics 26, 149-178.

7.David P. Echevarria, (1997) "Capital investment and the profitability of fortune 500 industrials: 1970-1990", Studies in Economics and Finance, Vol. 18 Iss: 2, pp.3 - 35.

8.Francisco Starke, Rangamohan V. Eunni, Nuno Manoel Martins Dias Fouto, Claudio Felisoni de Angelo, (2012) "Impact of ISO 9000 certification on firm performance: evidence from Brazil", Management Research Review, Vol. 35 Iss: 10, pp.974 - 997

9.Irina .B, Elvira. Z, 2014, return on equity and company characteristic: an empirical study of industries in Latvia, the eighth International Days of Statistics and Economics, Prague, September 11-13, 2014.

10.Jorge. R, 2005, Requirements for the Degree of doctor of philosophy in management science, the University of Texas at Dallas, ProQuest Information and Learning Company.

11.Marian.S, Daniel. C, Dalia. S, 2012, The Correlation between the Return on Assets and the Measures of Financial Balance for Romanian Companies, international journal of mathematical model and methods in applied sciences, Issue 2, Vol.6 
Journal of Social Sciences (COES\&RJ-JSS), 5(4), pp. 540-547

12.Muaaz A. ALasqah, 2012, ideal assets utilization and firm value (Exploratory Study), Social Science Research Network.

13.Naser. I, Dariush. F, Setare. S,2013, The Effect of Size, Return on Sales ,Leverage, Fixed Assets, Industry And Ownership on Effective Tax Rate in the Listed Companies of Tehran Stock Exchange, interdisciplinary journal of contemporary research in business, vol 5, no 1 . 